Meirbaev B.B., Pardabekov D.A.

\section{Religion in a globalized world}

Мейрбаев Б.Б., Пардабеков А.А.

Религия в глобализирующемся мире

Мейірбаев Б.Б., Пардабеков А.А.

Ғаламдану әлеміндегі дін
In this work the religion problem in the globalized world is described, the main problems of modern religion from the point of view of a ratio of political sphere of life, society and religion, relationship between various religions and improvement of relationship between people of all world community.

In modern world, humanity has reached the enormous scientific and technological progress, which is not compatible with the moral understanding of many people, and the consequences of human actions. When humanity faces the threat of self-destruction, a science without religion does not solve today's problems that ultimately leads to the new way of development of the various religious communities. The phenomenon of religion and belief does not run its course and could not go out of the relevance and importance in the future, while humanity has not yet come to a consensus on peace and harmony.

Key words: religion, belief, globalization, spirituality, tolerance.

В Аанной работе освещается проблема религии в глобализирующемся мире, основные проблемы современной религии с точки зрения соотношения политической сферой жизни общества и религии, взаимоотношений между различными вероисповеданиями и совершенствование взаимоотношений между ^юдьми всего мирового сообщества.

В современном мире человек Аостиг огромного научно-технического прогресса, который не совместим с нравственным пониманием многих ^юдей, а также последствий человеческих Аеяний. КогАа человечество стоит переА угрозой самоуничтожения, сама по себе наука без религии не Аает решения современных проблемы, что в конечном итоге приводит к новому толчку развития различных религиозных объединений. Феномен религии или веры не исчерпает себя и не угаснет актуальность и значимость в ближайшем будущем, пока человечество не придет к общему консенсусу о мире и согласии.

Кмючевые слова: религия, вера, глобализация, Ауховность, томерантность.

Бұл мақалада жаһандану жағдайындағы бүкіл дүние жүзіндегі Аіни мәселелер мен қазіргі діни ахуал саяси көзқарас тұрғысында қарастырылған. Сонымен бірге дүние жүзіндегі қоғамның діни сенімі мен діни қарым-қатынасының өзара байланысы салыстырмалы түрде сарапта^ды.

Заманауи әлемде адамзат көптеген адамдардың моральдық түсініктеріне үйлесімді емес зор ғылыми-техникалық прогреске жетті. ААамзат өзін-өзі жою қаупінің алдында тұрған кезде, ғылым Аіннің көмегінсіз өзекті проблемаларға шешім таба алмайды, ақырында бұл мәселе түрлі Аіни бірлестіктердің жаңа даму жолына әкеледі. Сондай-ак адамзат бейбітшілік пен келісімнің жалпы консенсусына жетпейінше, Аіннің және наным-сенімнің құбылыстарының өзектілігі мен маңыздылығы жақын арада сөнбейді.

Түйін сөздер: дін, сенім, жаһандану, төзімділік, руханилық. 


\section{RELIGION IN A GLOBALIZED WORLD}

\section{Introduction}

In the conditions of the globalized world, criteria of interreligious cooperation change and in this regard social functions of religion are transformed. It would be desirable to note that all political programs or political ideologies always control the number of presence at them of religious doctrines.

At all times the person always aimed to understand those events which take place around him, trying to explain why everything occurs a certain turn, in what a sense of existence of the person and what his role on the earth. The task of religion consisted in provision of responses to all these questions. The persons first outlook of essence of human life began to develope.

Eventually there are more accurate definitions to moral values and the philosophical outlook is changed to religious, thereby, having marked transition of mankind to new conscious level. But, despite discoveries in various areas, such as biology, physics, mathematics, astronomy, chemistry and set other sciences which cardinally change outlook of the modern person the religion did not become obsolete to this day.

At all times development and processes of globalization the religion has main functions which influence outlook and the relation in society in general.

\section{Main part}

In the 20th century there was laicization theory which explained the role of religion in the modern world. Adherents of this theory claimed that scientific and technical progress, already, by the beginning of the 21 st century will force out religion, and at underdeveloped countries there will be a belief in supernatural forces. The was laicization hypothesis in the second half of the $\mathrm{XX}$ century began to be confirmed, as violently developed in this period and found millions of adherents of atheism and agnosticism theory, however the end of XX - the beginning of the 21st century were marked by fast gain of number of the believing people and development of a number of new religions.

In the modern world process of globalization affected also the religious sphere, in this regard in the world gain popularity the 
main world religions, and remains less supporters of ethnoreligions. The situation in Africa is an example of it - when more than a century ago among the population of African states supporters of local ethnoreligions were more prevailed. Today all Africa can be divided conditionally into two zones Christian and Islamic.

Nowadays as the most widespread religions (world religions) are - Christianity, Islam and the Buddhism; each of them has over one billion adherents. Also, the large number of adherents is in other religious associations, such, as: Hinduism, Judaism, Taoism, Sikhism and other beliefs.

We endure a turning point in the history, and depends on our individual actions whether will begin society to move forward from this point to new progress or it will roll down, regenerating in some new Middle Ages.

It is clearly necessary to understand that recession of culture which we observe now, arises not from scratch. While each certain individual will not begin to understand that he is a creator of own destiny, he will not be able fully to keep in effective contact with society and to protect himself.

It is clear to all that society is capable to coexist peacefully for thousands of years if hostile forces do not attack it, not from within or outside. If there is such attack, first of all religion, national heroes, leaders of this society, and also integrity of his citizens become the main targets.

"Awareness of the unity with society comes first of all through religion. It appears because you endured something together with others" this quote shows us true essence of understanding of religion in the modern world [1].

In the recent past the religion took the ruthless battering from all directions, taught that it "opium for the people" that all this delusion, is not scientific and primitive, however, the main, though the hidden target of all these attacks to organized religion was something simpler: spirituality of the person, peace of mind and self-respect.

In the course of globalization in the $20-21^{\text {st }}$ centuries world religions got rough flourishing, but also numerous religious trends did not stand still, actively extended and developed: neoshamanism, neopaganism, scientology, Neo-Hinduism, the Agni Yoga, the Church of Perfect Liberty. It is only a small part of new religious trends hundreds of thousands of adherents having at the moment. In the conditions of globalization, people had a huge choice of various religious beliefs, and in the majority of the countries it is already impossible to call present society oneconfessional.
Returning on twenty years ago, receiving knowledge and education from materialistic positions, our society assumed that various religious organizations cease to influence public life and in this regard do not exert impact on outlook of people any more.

Nowadays, there is a noticeable activization of religious associations which directly try to participate in the solution of a number of urgent problems of the present. This phenomenon happens in most the states, with various economic and social indicators of development where any religions are widespread. Activization of religious activity concerned also the Republic of Kazakhstan where a time interval of formation of the independent, secular state promoted strengthening of missionary activity.

In the nineties, there where the state did not pay due consideration, various religious organizations in the region came with the laws which, to some extent could hold chaos which could be to appear. Consequences of such omission began to be shown, the prevalence of religious laws took over precepts of law up. Regulation of the relations with the government via through the legal levers became very difficult. Now it is necessary not only administrative impact on the religious organizations, but also active dialogue with them. In cases if the contract will be not reached, the subsequent scenarios are not predictable.

"History of all times and nations very convincingly demonstrates that the strongest incentives and considerable creative achievements proceeded from direct, not turbid belief which the religion inspires to the followers leading active life, the strongest incentives and considerable creative achievements proceeded, and in the field of social it is not less, than in the field of art and science." [2].

Flourishing of world religions and emergence of huge number of new religious trends depends on spiritual and psychological needs of people. In the modern world in the majority of the countries of the politician and religion are divided, and the religious organizations cannot have significant effect on political or civil processes in the country, however problems of religion significantly did not change in comparison with the last centuries.

And still in some states the religious organizations or priests exert huge impact on political and social processes. It is worth to remember that the religion forms outlook of believers, at the same time even in the secular states the religion mediately influences people and society in general. 
In the modern world the religion performs such functions as:

- the satisfaction of spiritual needs, is search of global philosophical answers;

- regulatory and educational functions, it is the set of certain moral standards where each believing person has to follow rules and norms;

- consolatory function, finding of peace of mind;

- communicative function, association of group of people of one faith.

In total it is possible to tell that the religion in itself is the goodnes. Nowadays, the set of the nongovernmental humanitarian organizations in the world has the religious beginning and are formed by the believing people.

But nevertheless, the religion has also a reverse of the medal which cannot be denied. Such phenomena as: hatred to other religious beliefs, up to the most tragic consequences; non-recognition, and sometimes even intervention to intellectual, scientific and art development; opposition to social and political freedom; haughty and stubborn statement of the validity of the belief.

Active development of world religions and emergence big quantity of new religious trends at the beginning of the XXI century rendered ambiguous reaction in society. So society was divided presumably into two camps, one welcome revival of religion, and others expresses categorically opposite point of view, reasoning it not with desire of influence of religious associations on society in general.

If to characterize the relation of modern society to religion, then it is possible to notice some tendencies applicable practically to all countries:

- more loyal relation of citizens to religions which are considered traditional for their state, and more hostile - to the new currents and world religions "competing" with traditional belief;

- increase in interest religious cults which were widespread far back in the past, but were already almost forgotten until recently (attempts to revive belief of ancestors);

- emergence and development of religious trends which are symbiosis of a certain direction of philosophy and dogmas from one or at once several religions;

- increase of a Muslim part of society in the countries where some more decades this religion was not really widespread;

- attempts of religious communities to lobby the rights and interests at the legislative level;

- emergence of the currents counteracting increase in a role of religion in life of the state [3].
In spite of the fact that the most part of society it is tolerant to treat various beliefs and their adherents, however attempts of some believers to actively impose the beliefs and rules to others, causes a protest in other supporters of religious beliefs, atheists, and also agnostics, what can lead to conflict situations.

There is a popular belief that the religion is a source of many conflicts and wars, but if we more attentively sort the conflicts taking place, then we will be able to understand that nowadays there are no purely religious wars. The religious conflicts have more political aspect, trying to exploit religion.

The majorities of the modern conflicts in various countries arose and arise because of desire of national religious minorities of these countries in political and religious independence.

In spite of the fact that the set of religions does not adhere only to pacifistic views, all of them have certain rules which define in what cases aggression or war can be justified. Practically all religious doctrines preach the most moral way of behavior in the conditions of the compelled conflict, any kinds of aggression, unjustified cruelty are forbidden, while justice and search of ways to reconciliation are encouraged.

If we look at history, we can see that the main reasons for the majority of military collisions were breeding and national discord, as well as the fight for the spread of atheistic ideologies, moral system most often relied on the principle "the end justifies the means". The religion constrains these motives and bears reconciliation to the conflicting parties, but religious doctrines were often rejected away when became on the way of human aggression [4].

Various religious systems have own understanding of many questions that often leads to the conflicts, but society have the general beliefs and in many respects similar moral values, religion in itself not to become an aggression source. The conflict can take place between various religions when there is a misunderstanding and opposition of different opinions, beliefs and customs. Each of the parties is convinced that their own judgments are correct and surpass views of opponents. It would be desirable to emphasize that the similar conflicts become the most dangerous when accessory of a certain group of believers is closely connected with national consciousness of people. The reason of similar aggressions is a lack of universal values, tolerances which need to be cultivated in people since the childhood, despite the available distinctions in the world.

Why there is this dark side of religion? It occurs because that in each person there is not only a light, 
but also dark beginning. In spite of the fact that religious ideals and ethical standards appeal to the best party of human nature, the evil in the person sometimes subordinates to itself religion. Therefore before to us to take out the judgment, it is necessary to check as far as this or that negative religious activity is approved or comes true the religious doctrine. You will hardly find such approval. Even founders of world religions often condemned modern religious practice by it [5].

Founders of all religious dogmas applied similar and at the same time different forms of ceremonies, and also structures of the religious organizations. At all the universality, religious beliefs have concrete culture and the language environment, a print of the identity of their founders and a historical situation in the period of life of the founder. All religious systems at all the similarity have a large amount of distinctions.

Difficulties of understanding can arise in that case when believers of one religion proclaim that only their religion is true, and all other people are mistaken or at all their religion does not matter.

Nobody has to prove the validity of a way of the rescue by the attack and belittling the advantage of other religions. Often such behavior among believers characterizes only own uncertainty. When the believing person is confident in the views, other beliefs and traditions will not be for him an irritation object and on the contrary will enrich his outlook.

If we track process of history of religion, then we can perfectly see how gradually from a big variety of various beliefs that was inherent only in one tribe, passed to national religions and then to universal, overcoming cultural, national, linguistic and racial barriers.

Religious figures, especially in the modern world, recognize a set of the mistakes made in the past, and it strengthens their aspiration to dialogue. All advanced religious associations and their figures promote search of universal values, by dialogue, based on mutual respect for other beliefs which will be able to overcome further historical distinctions and help in finding of unity at all variety.

Perhaps, there will be a veracious statement that an integral part of human history is the religion with all its aspects. If to consider religion from various points of view and from various temporary positions, the claim that without religion man would not be a man or without religion he would become much better and more perfect, all of them will be faithful, however the religion is a reality and it needs to be perceived properly.

Value of religion in life of certain people, societies and states a miscellaneous. For example,
We will compare two people: one - adhering to canons of any strict and closed sect, and another leading a secular life and absolutely indifferent to religion. The same example can be applied also to various societies and the states: one live under strict laws of religion, others give to the citizens free rain in questions of belief and do not interfere with the religious sphere at all, the third hold religion under a ban. During all history the question with religion in the same country can change. And faiths are not similar at all in those demands which they make in relation to the person in the laws of behavior and codes of morals. Religions can rally people or separate them, inspire for creative activity, for feats, call for inaction, the real estate and observation, to help distribution of literature and development of art and at the same time to limit any spheres of culture, to impose the bans on separate kinds of activity, sciences, etc. Value of religion always should be considered specifically in a certain society and during the set period. Its role for all public, for separate group of people or for the specific person can be various [6].

In the globalized world ideological, cultural and social and economic ties of the people of Islamic space actively prove, there is a formation of transnational political consciousness. The population of the Islamic countries, defending the foundations, will aspire that the West did not influence their social and state system in any way. Islamic fundamentalism and fanaticism as the main ideological sources of aggressive anti-Westernism will amplify, what force the West would not use against them. The pro-American modes in these countries will move away from the people and can be violently overthrown by it.

We see that in the conditions of globalization the religious factor is of particular importance as for the masses which see in religion a source and means of preservation of cultural values, and for the individual subjects of globalization using it for achievement of specific goals. In this context the opinion of the Russian mystic writer Daniel Andreyev is interesting: "It is significant that religious faiths before all proclaimed international ideals of a brotherhood, appear in a rear guard of general aspiration to world now. Perhaps, specific, characteristic of them is in focusing on the internal person, neglect by all external affects, and carry to external also a problem of social organization of mankind. But, if to peer more deeply, if to tell publicly what is told usually only in narrow circles of the people leading intensive religious life, then something will be found, not all considered. It is the mystical horror which arose at the 
time of the ancient Roman empire before the future association of the world, it is insatiable alarm for mankind because in the uniform universal state the trap had a presentiment from where the only exit will be to absolute autocracy, to a kingdom of "this prince of Peace", to the last cataclysms of history and to its catastrophic break".

The reason for that, probably, that in the religious sphere of life of society, perhaps, as in any other link of spiritual culture, historical memory, the moral principles and the belief uniting people are connected, which in the unity develop a peculiar immunity against aspirations of the globalists which are deprived of the humanistic beginning. And perhaps the emphasis should be placed on the deep, eternal values, which could serve as a bridge, to which many aspire in hopes to find a sincere support and which would help "глобальному человейнику" to go (A. Zinoviev) through difficult times [7].

Thus we have to make a start from a situation in the world. During acquisition by the world of monopolarity, our future can appear under the threat. In general, as we can see, a situation in the world it is impossible to call idle time.

Therefore, without finding a support in public institutes, people will look for and reach for religion, and the state will always look for ways of impact on people so and to influence religious institutes.

Thus, we must proceed from the situation in the world.During acquisition by the world of monopolarity, our future can appear under the threat. In general, as we can see, it is impossible to call a situation in the world quiet.

Therefore, without finding a support in public institutes, people will look for and reach for religion, and the state will always look for ways of impact on people so and to influence religious institutes.

Nowadays, it is obvious that the religion exerts notable impact on life in society and that it undergoes considerable and irreversible changes. But it is almost impossible to give a certain forecast of rather further opportunities or development of religion in the future. The extensive experience of insolvent forecasts in the 20th century showed that at prompt and grandiose achievements in various fields of science, the religion does not lag behind the globalized world and contrary to everything gains more and more steam forming various new religious trends, attracting new adherents in the ranks.

The science could open many questions of knowledge of the world facing the person, and could also seize forces of nature. In the modern world, the person made huge scientific and technical progress which is not compatible to moral understanding of many people, and also consequences of human acts. When the mankind faces self-destruction threat, the science in itself without religion does not give the decision modern problems that finally leads to a new push of development of various religious associations.

\section{Conclusion}

In the conclusion it is possible to tell that the phenomenon of religion or belief will not sputter out and relevance and the importance will not die away in the near future while the mankind does not come to the general consensus about peace and harmony.

\section{References}

1 Ron Habbard L. Vliyanie religii v obschestve. // [Elektronnyi resurs: http://ru.volunteerministers.org/l-ron-hubbard.html]. M. Plank. Vortrage uns Errinerungen. - S. 319.

2 «Religiya v sovremennom obschestve» // [Elektronnyiy resurs: http://sam-sebe-psycholog.ru/].

3 Fridrih Maks Myuller. Vvedenie v nauku o religii.: Chetyre lekcii, prochitannye v Londonskom Korolevstve v fevrale marte 1870 goda. / Per. S angl., predislovie I komentarii E.S. Elbakyan. Pod obwey redakciey A.N. Krasnikova. - M.: Knignyi dom «Universitet»: Viswaya wkola, 2002. - 264 s.

4 Losev A.F. Filosofiya. Mifologiya. Kultura. - M.: Politizdat, 1991. - 525 s.

5 Volkov A.P. Vidish li tyi svet svoey zvezdyi. - Riga, 1992.

6 S. Pankin. Istoriya mirovyih religiy: konspekt lektsiy. - М.: Эксмо, 2008. - $30 \mathrm{~s}$. 